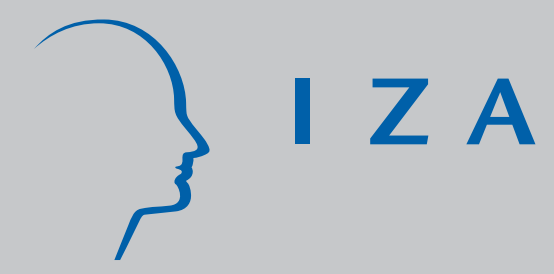

IZADP No. 1621

Structural Labor Market Changes in France

Marcello Estevão

Nigar Nargis

J une 2005 


\title{
Structural Labor Market Changes in France
}

\author{
Marcello Estevão \\ International Monetary Fund
}

Nigar Nargis

University of Dhaka

and IZA Bonn

\section{Discussion Paper No. 1621 \\ June 2005}

IZA
P.O. Box 7240
53072 Bonn
Germany

Phone: +49-228-3894-0

Fax: +49-228-3894-180

Email: iza@iza.org

\begin{abstract}
Any opinions expressed here are those of the author(s) and not those of the institute. Research disseminated by IZA may include views on policy, but the institute itself takes no institutional policy positions.

The Institute for the Study of Labor (IZA) in Bonn is a local and virtual international research center and a place of communication between science, politics and business. IZA is an independent nonprofit company supported by Deutsche Post World Net. The center is associated with the University of Bonn and offers a stimulating research environment through its research networks, research support, and visitors and doctoral programs. IZA engages in (i) original and internationally competitive research in all fields of labor economics, (ii) development of policy concepts, and (iii) dissemination of research results and concepts to the interested public.
\end{abstract}

IZA Discussion Papers often represent preliminary work and are circulated to encourage discussion. Citation of such a paper should account for its provisional character. A revised version may be available directly from the author. 


\section{ABSTRACT}

\section{Structural Labor Market Changes in France*}

France posted remarkable gains in employment in the second half of the 1990s, suggesting that, beyond cyclical factors, structural unemployment may have changed in the period. We provide a novel methodology to separate structural from cyclical labor market changes and apply it to French household level data from 1990 to 2000. We show that the equilibrium relationship between real wages and unemployment has improved significantly in France in the second half of the 1990s. Further calculations suggest that long-term unemployment will decline substantially in France with respect to its average level in the 1990s if this improved trade-off is not undone.

JEL Classification: D2, E2, J23

Keywords: employment, wages, bargaining, structural change, labor market

Corresponding author:

Marcello Estevão

International Monetary Fund

European Department, HQ 8-313E

700 19th Street, NW

Washington, DC 20431

USA

Email: mestevao@imf.org

\footnotetext{
* We greatly benefited from insightful discussions with Luc Everaert and Robert Ford and got valuable suggestion from J.S. Butler, Bruno Crépon, Jörg Decressin, Antonio Spilimbergo, and seminar participants at the IMF, the Conseil d'Analyse Économique, and the 2002 Econometric Society meeting in Venice. Didier Blanchet provided crucial answers to many data questions. The views expressed in this paper are those of the authors and do not necessarily represent those of the IMF or IMF policy. All errors and omissions should be attributed solely to the authors.
} 


\section{INTRODUCTION}

The French economic expansion of the second half of the 1990s was characterized by a sharp rise in employment and reduction in unemployment. Employment increased by about 1.8 million people, a record in such a short period of time for France, and the unemployment rate fell from a peak of 12.3 percent at the beginning of 1997 to 8.6 percent in mid-2001. This performance is all the more noteworthy in that output grew less during this period than in previous expansions. Finally, nominal wages were surprisingly sluggish during the expansion and, as a result, real wage growth inched up 13/4 percent from 1997 to 2000. The combination of high employment and relatively modest output growth led some analysts to characterize the upswing as "rich in employment."1

Existing studies suggest that job-rich growth may have been caused in part by changes in the basic parameters of the wage setting mechanism resulting in a rightward shift in a laborsupply like relationship between real wages and employment. ${ }^{2}$ Other studies focus on the positive labor demand effects of the cuts in firm's social security contributions enacted by the French government beginning in 1993. ${ }^{3}$ This paper provides direct evidence that the trade-off between real wages and unemployment has indeed improved in France in the second half of the 1990s, which is a direct evidence of a structural improvement in labor market functioning. Such a

\footnotetext{
${ }^{1}$ See, for instance, Pisani-Ferry (2000) and Decressin and others (2001). As discussed in the latter paper, in the second half of the 1990s, the unemployment rate fell sharply and wage growth was weak also in Spain and, to a lesser extent, in Italy. The Netherlands and the United Kingdom posted very large declines in unemployment beginning in the 1980s.

${ }^{2}$ Decressin and others (2001).

${ }^{3}$ Crèpon and Desplatz (2001).
} 
structural shift accounts for a large share of the job growth associated with sluggish wages observed in the second half of the 1990s, but also implies a pickup in investment rates as the economy converges to its long-run equilibrium. Therefore, abstracting from business cycle effects, the previous job-rich growth phase could be followed by a "capital-rich” growth period. It is shown here that if this moderation is not reversed in future years, the equilibrium unemployment rate will be halved in the long run, although this estimate is subject to some uncertainty.

The methodology in the paper departs from a theoretical framework based on the bargaining models described in Layard et al. (1991). As an empirical counterpart, we present an econometric model of wage determination. The data come from the Enquête Emploi, a French household level employment survey. The estimates from this model are used to construct a “wage curve” in which individual pay is linked to the local unemployment rate controlling for observable individual characteristics, a paradigm set by Blanchflower and Oswald (1994). Shifts in this curve are then viewed as structural labor market changes because cyclical unemployment changes would affect wages through movements along the wage curve. The econometric exercise points to a significant improvement in the trade-off between real wages and unemployment, which is consistent with many factors, including a decline in unions’ bargaining power, increased preference away from wages and towards employment (“wage moderation”), shifts toward more labor-intensive technologies, and reductions in taxes on labor income.

The paper is organized in the following sections. Section II describes key developments in the French labor market in the 1990s. Section III develops a theoretical bargaining framework that is used in the econometric model laid out in section IV. Section V presents the econometric 
estimates. Section VI discusses the implications for long-run equilibrium unemployment rates and the possible causes for such a structural change in France. The paper concludes with section VII.

\section{FRENCH LABOR MARKET PERFORMANCE IN THE 1990S}

The French economy grew robustly between 1997 and 2000, without signs of price acceleration. Labor market performance was also quite strong, with harmonized unemployment rates falling from 121/4 percent in mid-1997 to 81/2 percent in May 2001. Employment rose particularly sharply during the same period with a yearly average of 400,000 additional jobs, substantially more than the 1987-1989 expansion, when average annual employment increased by 270,000. Taking into account that average output growth between 1997 and 2000 was 0.8 percentage point below the average growth at the end of the $1980 \mathrm{~s}$ - and assuming the same growth in labor productivity only for the sake of comparison-the recent recovery should have produced about 100,000 less jobs than the previous one. As discussed in Pisani-Ferry (2000), part of this difference can be explained by a change in the thrust of government policies toward reducing unemployment rates mainly among less skilled workers. ${ }^{4}$ However, given current

\footnotetext{
${ }^{4}$ Pisani-Ferry (2000) provides an overview of all the studies measuring the effect of recent government policies on employment. His analysis is limited to the period going from 1997 to 1999 but an update of the table shown in page 29 of his report would result in similar conclusions for annual averages from 1997 to 2000. Among the most important policy changes are the cuts in social security contributions for firms hiring low-wage earners since 1993 and the three laws aiming at the reduction of the standard workweek to 35 hours enacted after 1996.
} 
estimates for these effects, about half of the better employment performance in the latter period remains unexplained.

A compilation of data from the Enquête Emploi shows that unemployment rates have declined steadily since the 1997 peak (Table 1). By 2000, the proportion of the population between 15 and 64 years of age that is employed — the employment rate-reached 61 percent, the largest value in the decade, albeit still low by international standards. ${ }^{5}$ The proportion of full-time workers in total employment declined from 87 percent in 1990 to 82 percent in 2000, due to increased acceptance of part-time arrangements. Average hours of work per week also declined steadily throughout the decade. The two largest annual declines in average hours of work occurred in 1999 and 2000 even as economic activity expanded vigorously, reflecting the various workweek reduction laws introduced since 1996. A breakdown of employment by gender shows slightly larger growth in the employment rate among women since 1994 (Figure 1). Youth employment increased appreciably over 1997-2000 and the employment rate for this group edged up after hitting a trough in $1997 .{ }^{6}$ The reduction in the unemployment rate has been larger among younger workers than prime working-age and older individuals.

\footnotetext{
${ }^{5}$ See OECD (2001). For instance, employment rates in Germany (66.3 percent), the U.S. (74.1 percent) and the Netherlands (72.9 percent) were much larger than in France. Italy (53.4 percent) and Spain (56.1 percent) continue to trail France. The OECD average was 65.7 percent.

${ }^{6}$ The increase in youth employment rate is not only the result of the more volatile labor supply in this demographic group but also of the introduction of a sizable youth employment policy (emplois jeunes) in 1999.
} 
More importantly for this paper, real hourly wages increased only by 3.2 percent during 1990-2000 in France (an average annual rate of 0.3 percent), well below total factor productivity growth adjusted for the labor share (about 1.4 percent per year)—our measure of labor augmenting technical progress. ${ }^{7}$ Real wages grew only $13 / 4$ percent in the recent expansion from 1997 to $2000 .^{8}$ Real annual earnings increased at an even lower rate than real hourly wages throughout the decade. The strong job creation associated with tame real wage growth suggests that structural changes had operated in the labor market, as cyclical factors would have caused real wages to increase together with employment. In any case, these developments point to the importance of using microeconomic data to control for the many composition changes in the labor market during the 1990s and the need for a succinct measure of structural labor market improvements.

\footnotetext{
${ }^{7}$ Technological progress is assumed to be labor augmenting (Harrod neutral) to allow for balanced growth in a dynamic setup. The measure proposed here is a proxy for this variable and has also been used in Blanchard (1997).

${ }^{8}$ Part of the substantial real wage increase between 1990 and 1993 was actually a figment of composition effects during the recession years: less-skilled workers (and, thus, low-wage earners) were the first to be fired and that raised average wages.
} 
Table 1. Key Labor Market Indicators, 1990-2000

(Weighted means and standard errors ${ }^{1}$ )

\begin{tabular}{|c|c|c|c|c|c|c|}
\hline Year & $\begin{array}{c}\text { Real } \\
\text { Annual } \\
\text { Earning }^{2}\end{array}$ & $\begin{array}{c}\text { Real } \\
\text { Hourly } \\
\text { Wage }^{2}\end{array}$ & $\begin{array}{c}\text { Weekly } \\
\text { Hours } \\
\text { Worked }\end{array}$ & $\begin{array}{c}\text { Employment } \\
\text { Rate (\%) }\end{array}$ & $\begin{array}{c}\text { Full Time } \\
\text { Employed } \\
\text { Rate (\%) }\end{array}$ & $\begin{array}{c}\text { Unemployment } \\
\text { Rate (\%) }\end{array}$ \\
\hline 1990 & 87982.54 & 41.48 & 39.94 & 59.92 & 87.08 & 9.24 \\
& $(288.08)$ & $(0.16)$ & $(12.28)$ & $(0.15)$ & $(0.14)$ & $(0.11)$ \\
\hline 1991 & 89007.05 & 42.00 & 40.38 & 59.94 & 86.94 & 9.11 \\
& $(308.03)$ & $(0.16)$ & $(12.51)$ & $(0.15)$ & $(0.14)$ & $(0.11)$ \\
\hline 1992 & 90388.80 & 42.60 & 40.17 & 59.96 & 86.29 & 10.12 \\
& $(307.57)$ & $(0.16)$ & $(12.36)$ & $(0.15)$ & $(0.14)$ & $(0.11)$ \\
\hline 1993 & 91921.23 & 44.16 & 39.965 & 59.02 & 85.00 & 11.21 \\
& $(319.30)$ & $(0.17)$ & $(12.62)$ & $(0.14)$ & $(0.14)$ & $(0.11)$ \\
\hline 1994 & 89466.60 & 43.44 & 39.958 & 58.26 & 83.99 & 12.47 \\
& $(319.35)$ & $(0.22)$ & $(12.91)$ & $(0.14)$ & $(0.15)$ & $(0.12)$ \\
\hline 1995 & 88546.88 & 42.66 & 39.683 & 59.01 & 83.2 & 11.67 \\
& $(318.00)$ & $(0.17)$ & $(12.79)$ & $(0.14)$ & $(0.15)$ & $(0.11)$ \\
\hline 1996 & 87837.75 & 41.93 & 39.600 & 59.17 & 82.59 & 12.18 \\
& $(323.04)$ & $(0.17)$ & $(12.74)$ & $(0.14)$ & $(0.15)$ & $(0.12)$ \\
\hline 1997 & 88418.46 & 42.01 & 39.211 & 58.81 & 82.01 & 12.38 \\
& $(336.04)$ & $(0.18)$ & $(12.95)$ & $(0.14)$ & $(0.16)$ & $(0.12)$ \\
\hline 1998 & 88614.96 & 42.58 & 39.348 & 59.38 & 81.59 & 11.90 \\
& $(334.57)$ & $(0.19)$ & $(12.75)$ & $(0.14)$ & $(0.16)$ & $(0.12)$ \\
\hline 1999 & 88353.71 & 42.85 & 38.881 & 59.80 & 81.87 & 11.82 \\
& $(326.29)$ & $(0.20)$ & $(12.38)$ & $(0.14)$ & $(0.16)$ & $(0.11)$ \\
\hline 2000 & 87435.73 & 42.80 & 38.469 & 61.14 & 82.44 & 10.09 \\
& $(326.91)$ & $(0.35)$ & $(12.30)$ & $(0.14)$ & $(0.15)$ & $(0.11)$ \\
\hline
\end{tabular}

Source: Enquête Emploi and authors' estimates.

${ }^{1}$ The means and standard errors are weighted by individual sampling weights. The standard errors are in parentheses.

${ }^{2}$ Real earnings and wages in 1990 francs were obtained by deflating the respective nominal variables by the Consumer Price Index (CPI) for France. 
Figure 1. Employment and Unemployment Rates by Gender and Age Groups

\section{(Percent)}

Employment Rate by Gender

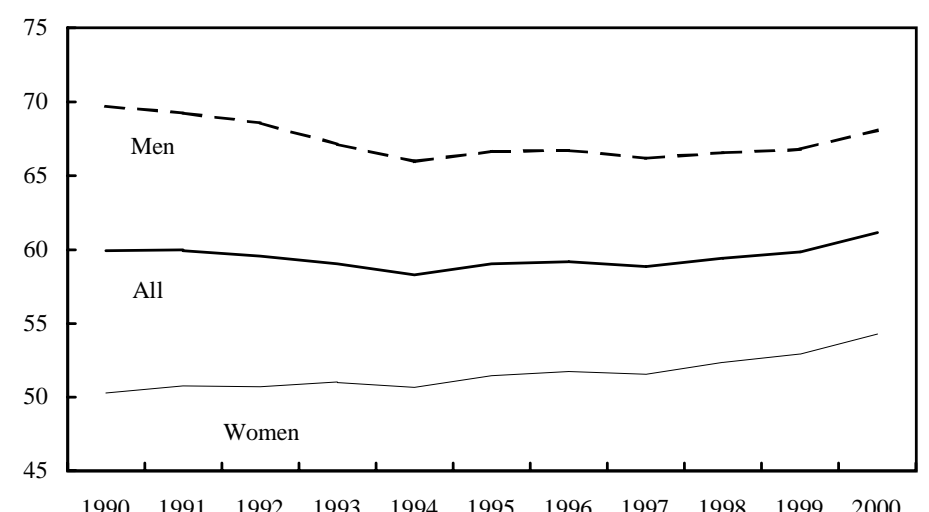

Unemployment Rate by Gender

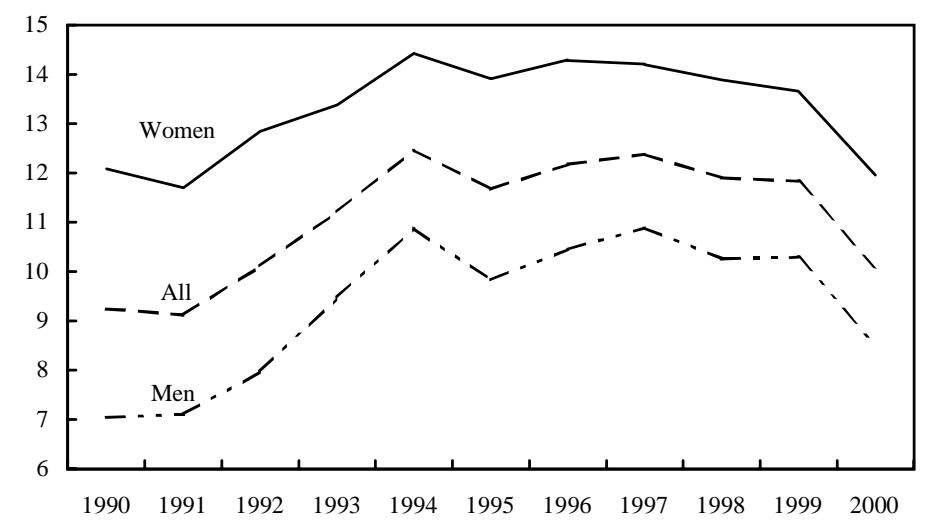

Employment Rate by Age Group

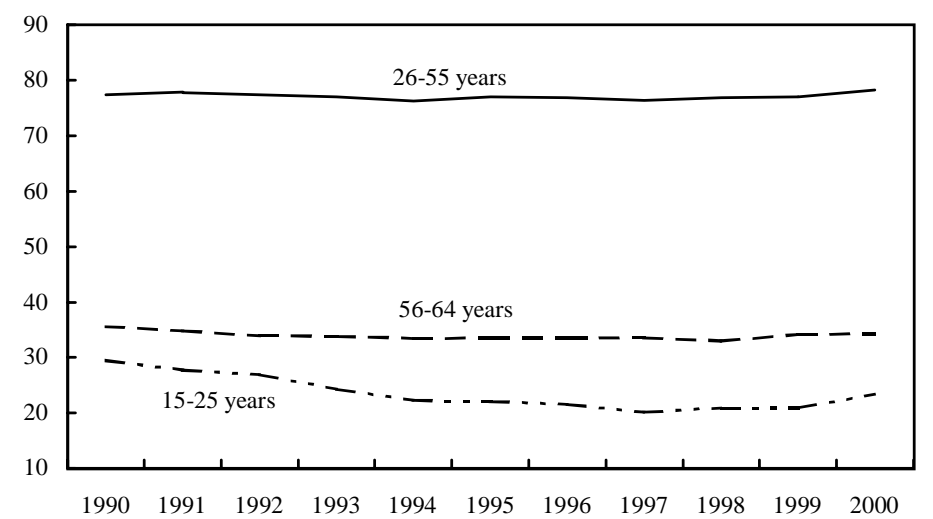

Unemployment Rate by Age Group

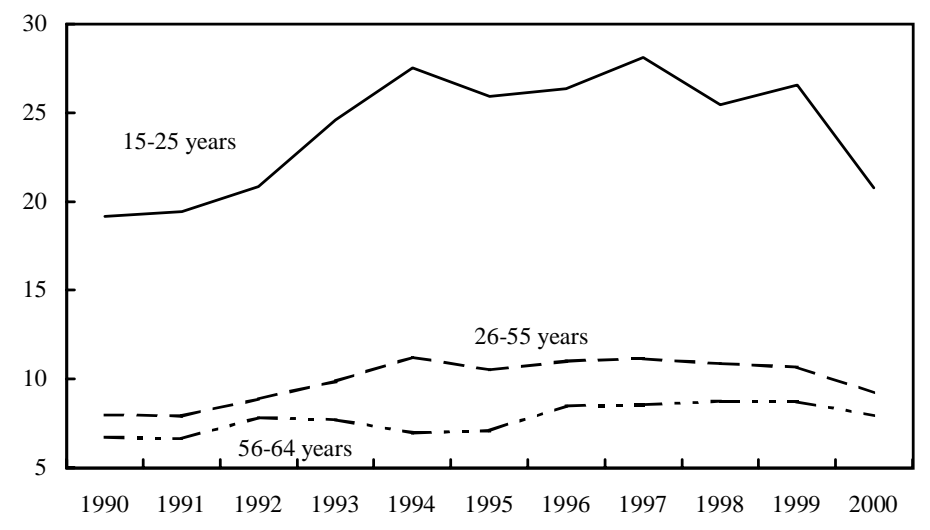

Source: Authorities, Enquête Emploi; and authors' calculations. 


\section{A BENCHMARK MODEL}

Most workers in continental Europe receive wages set by collective agreements negotiated between trade unions and employers, in contrast to the more competitive wage setting prevailing in the Unites States. This does not necessarily imply that the percentage of trade union members among all wage/salary earners is large, since unions may negotiate pay on behalf of the employees irrespective of their affiliation with the unions. Besides, the negotiation can occur at the national, regional or sectoral levels. France ranks as one of the lowest in terms of union membership (10 percent) among the continental European OECD countries, with more than 70 percent of all employees covered by collective bargaining agreements.

Not all firms in France are characterized by wage setting through negotiation between unions and firms, though. Abowd and Kramarz (1993) pointed out the existence of the incentive compensation system as a competing regime of wage determination in the manufacturing firms in France. Under this system, the firm and its employees accord on a wage that is incentive compatible, such that an employee's utility from providing high work effort is at least as great as the utility he could derive from offering normal work effort outside that firm. The wage offer also has to be feasible given the firm's profitability constraint. The firms that do not reach such an agreement with the employees operate on the labor demand curve using sector-level negotiated wage as given. In a static framework, this arrangement is equivalent to the right-to-manage model, which postulates that firms and unions bargain over wages but firms set employment unilaterally. The authors ruled out the third possibility of contracting regime, namely the efficient contracting, which implies joint determination of wages and employment. In addition, Abowd and Kramarz did not find any striking difference in the structure of wage determination between the 
firms with and without accords. So, the right-to-manage model can be used as a reasonable approximation of the way wages are set in France. ${ }^{9}$

Firms are assumed to determine employment by maximizing short-run profits given the negotiated wages and the stock of capital. ${ }^{10}$ On the other hand, unions take into consideration the employment effects when negotiating the wage. The profit maximization problem of firm $i$ is:

$$
\begin{aligned}
& \underset{N_{i}}{\operatorname{Max}} \Pi_{i}=P\left(Y_{i}^{d}\right) Y_{i}-W_{i}\left(1+t^{e}\right) N_{i} \\
& \text { s.t. } Y_{i}=T_{i} K_{i}^{\alpha} N_{i}^{1-\alpha} \\
& Y_{i}^{d}=\left(\frac{P}{P_{i}}\right)^{\varepsilon}, \varepsilon>1 \\
& Y_{i}^{d}=Y_{i}
\end{aligned}
$$

where $W_{i}, P_{i}, P, N_{i}, T_{i}, K_{i}, t^{e}$, and $\varepsilon$ represent, respectively, the bargained wage, firm-level price, economy-wide average price level, employment at the firm, total factor productivity, capital, the payroll tax rate paid by the firm, and the absolute value of the price elasticity of demand. The

\footnotetext{
${ }^{9}$ This model is formally equivalent to the basic framework discussed in Layard et al. (1991).

${ }^{10}$ The assumption of capital exogeneity determines the short-run character of the model in which an analysis of the optimal long-run growth path is irrelevant. Nickell and Layard (1997) and Daveri and Tabellini (2000) have focused somewhat on the relationship between the equilibrium unemployment rate and the optimal rate of capital accumulation.
} 
production function is assumed to be Cobb-Douglas in (1a), the demand for output is a function of its relative price with the aggregate price level taken as exogenous in (1b), and there are no costs to adjust labor to its optimal value. Solving this maximization problem and using the assumption that firms are identical-implying that the subscript $i$ can be dropped for all the variables in the first order condition of (1)_firms’ optimal demand for labor is

$$
N=\left(\frac{W\left(1+t^{e}\right)}{P} \frac{\varepsilon}{(\varepsilon-1)(1-\alpha)}\left(T K^{\alpha}\right)^{\frac{1-\varepsilon}{\varepsilon}}\right)^{\frac{\varepsilon}{\alpha(1-\varepsilon)-1}}
$$

Note that the elasticities of labor demand to exogenous changes in the negotiated wages or in social security taxes, $\varepsilon_{N W}$, and the share of labor costs in profits, $\lambda$ - to be used belowdepend only on the demand elasticity, $\varepsilon$, and on the labor intensity of production, (1- $\alpha$ ).

The bargaining problem can be described as the maximization of a Nash function subject to this labor demand function:

$$
\underset{W}{\operatorname{Max}} \Omega=\left[N^{\gamma}\left(\frac{W}{C}-A\right)\right]^{\theta} \Pi
$$

s.t. $\quad N=N(W)$, from firm's profit maximization, where $N, W$, and $\Pi$ represent, respectively, employment, wage, and profits for a firm. $\theta$ measures workers' relative bargaining power and $\gamma$ indicates how much unions care about employment. $C$ is the consumer price index adjusted for the fiscal wedge between earned wages and workers' takehome pay. Defining $P_{C}$ as the net-of-tax consumer price index, $t^{c}$ as the consumption tax rate, $t^{d}$ as the income tax rate, and $t^{s s}$ as the social security tax rate, $C$ can be written as 


$$
C=P_{C}\left[\frac{1+t^{c}(X, T)}{\left(1-t^{d}(X, T)\right)\left(1-t^{s s}(X, T)\right)}\right]
$$

The observable individual characteristics of workers (X) and the index of technological growth (T) are the determinants of the individual consumption, income and social security tax rates in (4). In equation (3), A represents workers’ outside opportunities, which can be expressed as

$$
A=(1-u) \frac{W}{C}+u \frac{B\left(X, T, P_{C}\left(1+t^{c}\right)\right)}{C_{U}}
$$

where $u, W, B$, and $C_{U}$ are the unemployment rate, aggregate wages, worker's income when unemployed, and the consumer price index adjusted for the fiscal wedge on the income received when unemployed. The worker's income when unemployed is determined by individual characteristics, technological growth—which influences an individual's productivity in nonmarket activities — and consumer prices through indexation mechanisms. ${ }^{11}$ The unemployment rate is a proxy for the probability of finding work elsewhere in case of disagreement during the bargaining process.

The first-order condition of this bargaining problem yields:

\footnotetext{
${ }^{11}$ Blanchard and Katz (1997) enumerate the variables that might affect an individual's income when unemployed and pay particular attention to the importance of technological growth.
} 


$$
\frac{\theta \gamma\left(\frac{W}{C}-A\right) \varepsilon_{N W}+\frac{W}{C}}{\frac{W}{C}-A}=\lambda
$$

or

$$
\frac{W}{C}=m A,
$$

where $m=\frac{\theta \gamma \varepsilon_{N W}-\lambda}{1+\theta \gamma \varepsilon_{N W}-\lambda}=m\left(\theta, \gamma, \lambda(\varepsilon, \alpha), \varepsilon_{N W}(\varepsilon, \alpha)\right)$.

In words, real wages corrected for the tax wedge are a markup over workers' alternative income. This markup is higher when workers' bargaining power is stronger, when the demand for output and the demand for labor are less elastic, when the labor intensity of production is less, and when unions care less about the level of employment. Using the formula for $A$ as in equation (5) yields a wage locus,

$$
W=\frac{m u}{1-m(1-u)} B\left(X, T, P_{C}\left(1+t^{c}\right)\right) \frac{C}{C_{U}}
$$

Equations (2) and (8) determine equilibrium in the labor market for a given size of the labor force. Wages are higher when the ratio between the fiscal wedge on labor income and the fiscal wedge on unemployment benefits is larger. Therefore, to the extent that employed and unemployed individuals pay the same consumption price including taxes, indirect taxation (and the level of consumer prices) cancels out. If it were available, the tax-adjusted unemployment income would be the right "deflator" for wages in the estimation of the wage/unemployment locus described in (8). 
The relationship between wages and unemployment as generated in equation (8) can be summarized as:

$$
\frac{W}{B\left(X, T, P_{C}\left(1+t^{c}\right)\right)}=\tau\left(X, T, P_{C}\left(1+t^{c}\right)\right)^{*} f(m, u), f_{m}>0 \text { and } f_{u}<0
$$

where, $W, B$ and $\tau$ stand for the nominal hourly wage, the income a worker would receive if unemployed, and the tax wedge between labor income and unemployment income; $m$, as defined in (7) by $m\left(\theta, \gamma, \lambda(\varepsilon, \alpha), \varepsilon_{N W}(\varepsilon, \alpha)\right)$, is a composite structural parameter determining the position of the wage curve for a given tax wedge and its steepness; $u$ is the unemployment rate.

For a given rate of unemployment, wages will depend on how large the unemployment income corrected for its relative tax liabilities and on the structural parameter $m$. Ceteris paribus, the larger the unemployment income the bolder will be wage demands because in case of disagreement during the bargaining process the alternative scenario of being unemployed becomes less unattractive. When the unemployment rate increases, the probability of not finding a job also increases and wage demands will be more subdued. Whenever unions’ bargaining power becomes weaker ( $\theta$ is larger), or whenever unions give more value to employment levels vis-à-vis higher wages ( $\gamma$ is larger), the parameter $m$ decreases and wages will be lower for a given rate of unemployment. These are pure “wage moderation” effects. Wage moderation also affects the sensitivity of wages to changes in the unemployment rate.

Changes in production technology and product market conditions may also affect the relationship between wages and unemployment through variations in the other parameters in $m$. If 
technology is more labor intensive, such that $(1-\alpha)$ is higher, wage demands will be weaker because workers will incorporate the stronger effect of higher wages on employment. This would be reflected in lower share of labor costs in profits $(\lambda)$, or higher elasticity of labor demand to exogenous changes in the negotiated wages or in social security taxes $\left(\varepsilon_{N W}\right)$, or both. The same argument holds if the elasticity of product demand $(\varepsilon)$ is larger. Finally, changes in the tax wedge between labor income and unemployment income $(\tau)$ also shifts equation (9), which explains why many researchers have focused on the evolution of tax wedges in OECD countries to try to understand labor market developments.

\section{ESTIMATION}

With a view to identifying shifts in the wages/unemployment equilibrium locus in France in the late 1990s, we estimate a wage equation corresponding to equation (9) derived in Section III, using individual level data from the Enquête Emploi (see Appendix I for description of data). The following log-linear version is considered initially:

$$
\ln w_{i r t}=a+X_{i t}^{\prime} b+g \ln u_{r t}+d_{t}+d_{r}+e_{i r t}
$$

where ln refers to natural log, $w_{\text {irt }}$ is the hourly wage rate of individual $i$ living in region $r$ in year $t, X_{i t}$ is a vector of individual observable characteristics, $u_{r t}$ is the unemployment rate in region $r$ at year $t, d_{t}$ and $d_{r}$ are respectively temporal and regional dummies, and $e_{i r t}$ is an i.i.d. error term. 
The allowance for individual level variations in the measure of alternative income through the pure composition effects presents a substantial improvement in this study over the conventional practice of using aggregate measures of alternative income. As for example, Abowd and Lemieux (1993) measured alternative income at the firm level by using average wage of the industrial composite in Canada. The consideration that this aggregate measure may be inadequate to capture the variations in market alternatives leads them to use the provincial wage rates and the provincial unemployment rates as well to measure alternative wage.

A version of equation (10) has been used by Blanchflower and Oswald (1994) to show that, when estimating the relationship between regional unemployment and annual labor earnings, termed as the "wage curve", the elasticity of annual labor earnings with respect to regional unemployment rate is about -0.1 for virtually all the countries analyzed. ${ }^{12}$ Gianella (2000) provided the first evidence of a "wage curve" for France using a matched employer-employee panel data in the private sector from the Déclarations Annuelles des Salariés (DAS) and Echantillon Démographique Permanent (EDP) for the period from 1984 to 1995, and 1990 excluded. His estimates vary between -0.05 and -0.1 for males. Compared to the present paper, he used a different database, time period (including a missing year in the middle of the sample), and methodology.

In estimating the relationship between unemployment and wages from survey data, it is necessary to guard against possible inefficient estimation that would result from covariance

\footnotetext{
${ }^{12}$ These countries were Australia, Austria, Canada, Germany, Great Britain, Ireland, Italy, Netherlands, Norway, South Korea, Switzerland, and the United States. France was not part of their analysis.
} 
among individuals which is not entirely attributable to either their measured characteristics or the local unemployment rate (Moulton, 1986, 1990). To address this concern, the two-step estimation approach proposed by Card (1995) is used. In a first step, the following equation is estimated:

$$
\ln w_{\text {irt }}=a+X_{i t}^{\prime} b+\sum_{r, t} \omega_{r t} \cdot 1_{\text {Re gion } r} \cdot 1_{\text {Time }=t}+e_{i r t}
$$

This equation excludes the local unemployment rate, but includes interactive region and time dummies, whose coefficients can be interpreted as the average regional wage at time $t$ controlling for individual specific characteristics. As it was the case of equation (10), all regressors but the interaction term for region and year are included primarily to control for the changing composition of the labor force over time as well as for individual-specific alternative income and tax liabilities if unemployed. The interactive time and regional dummies capture aggregate price variations as well as technological progress (both important determinants of workers' income when unemployed) beside all other time/regional specific effects, including regional unemployment rates. The coefficients of these dummy variables can be interpreted as the hourly nominal wage for region $r$ at time $t$ once individual characteristics and idiosyncratic errors at the individual level are taken into account. In a second step, the adjusted wage variable—-the estimated coefficients of the interactive region and time dummies—is regressed on time and region effects as well as on the regional unemployment rate as shown in equation (12):

$$
\omega_{r t}=c+g \ln u_{r t}+d_{t}+d_{r}+e_{r t}
$$


To address possible simultaneity bias in equation (12) the lagged unemployment rate is used as instrument. $^{13}$

Several variations of equation (12) may prove to be important. First, the relationship between unemployment and wages may not be linear. In this case, higher order polynomials of the local unemployment rate can be used in the estimation of (12). Gianella (2000) found some evidence of a convex relationship between wages and unemployment in France. Second, since wages may not adjust immediately to variations in unemployment, lagged wages should be included, which is a common practice in the literature on the Phillips curve. ${ }^{14}$ Third, the elasticity of wages with respect to unemployment may depend on the relevant group of individuals under consideration. Blanchflower and Oswald (1994) and Gianella (2000) showed that this is the case. For instance, the sensitivity of wages to unemployment is a bit larger for men than for women. It may also vary by workers' skill-type. However, since the focus here is on average elasticities and individual characteristics are taken into consideration at least in the intercept of equation (10), this issue is not pursued further.

Finally, the model developed in section II shows that technological and preference shocks affect not only the intercept of the wage curve but also its steepness. However, estimates allowing for variations in angular coefficients while at the same time including time dummies for changing intercept would result in large standard errors. So, throughout the empirical exercise reported

\footnotetext{
${ }^{13}$ The bias results from the possibility that higher wages cause lower labor demand and thus a higher rate of unemployment.

${ }^{14}$ See Bell (1996) and Blanchard and Katz (1997).
} 
below, the elasticity of wages with respect to changes in the unemployment rate, given by $g$ in equation (12), is held constant over time. The effect of variations in the mark-up of wages over workers' alternative income ( $m$ in equation (9)) on the estimated wage curve is assumed to be captured by time dummies. These are intercept shifts and also capture any changes in the tax wedge parameter ( $\tau$ in equation (9)).

\section{RESULTS}

In the first step of estimation, the nominal log hourly wage is regressed on demographic characteristics, dummies for full-time employment status, educational groups and their interactions with age groups, industries, occupation types, and interactions for region and year, as shown in equation (11). The estimated coefficients from the first step regression are presented in Table 8 in Appendix II. Coefficient signs display the usual direction of impact on wage of individual characteristics such as age, gender, the number of children, marital status, and employment status. Having controlled for the individual specific variations, we turn to the estimates obtained from the second step regression.

The results of the second step regression (equation 12) presented in Table 2 are more important for the present purpose. In this step, the coefficients of the time/region interactive dummies estimated from the first step are, first, “deflated” by changes the consumer price index and a measure of technological progress. The technological progress index was measured by accumulating changes in total factor productivity scaled by the labor share. Then, the resulting variable was regressed on the log of regional unemployment rate and dummies for region and year. The instrumental variable (I.V.) estimate of the elasticity of the hourly wage with respect to 
the unemployment rate is -0.1 , the same value Blanchflower and Oswald (1994) found for several other countries using a different methodology. The smaller estimate (in absolute value) obtained by the OLS procedure is consistent with some simultaneity bias coming from a relationship between wages and unemployment driven by labor demand. The I.V. estimate indicates that wages are negatively correlated with local unemployment rates. It also shows that a doubling of the unemployment rate would be associated with a drop in hourly wages by 10 percent.

Table 2. Parameter Estimates from the Hourly Wage Regression

\begin{tabular}{|c|c|c|c|c|}
\hline \multicolumn{5}{|c|}{ Second Step $^{1}$} \\
\hline \multirow[t]{2}{*}{ Dependent Variable: } & \multicolumn{4}{|c|}{$\begin{array}{c}\text { Nominal Log Hourly Wage Adjusted for Individual } \\
\text { Characteristics }\end{array}$} \\
\hline & OLS & I.V. & I.V. & I.V. \\
\hline $\begin{array}{l}\text { Independent Variable }{ }^{2} \text { : } \\
\text { Log Regional } \\
\text { Unemployment Rate }\left(\mathrm{U}_{\mathrm{R}}\right) \\
\mathrm{U}_{\mathrm{R}} * \mathrm{U}_{\mathrm{R}} \\
\mathrm{U}_{\mathrm{R}} * \mathrm{U}_{\mathrm{R}} * \mathrm{U}_{\mathrm{R}}\end{array}$ & $\begin{array}{l}-0.0298 * \\
(0.0141)\end{array}$ & $\begin{array}{c}-0.0989 * * \\
(0.0295)\end{array}$ & $\begin{array}{c}-0.0428 \\
(0.0943) \\
0.0117 \\
(0.0190)\end{array}$ & $\begin{array}{l}-0.0696 \\
(0.0561)\end{array}$ \\
\hline
\end{tabular}

Source: Enquête Emploi and authors’ calculations.

${ }^{1}$ Standard errors are in parentheses. ** and * stand for $1 \%$ and $5 \%$ level of significance respectively.

${ }^{2}$ Other included independent variables are time dummies and regional dummies. Lagged unemployment rate was used as instrument for the contemporaneous rate in the I.V. estimation. The square and the cube of lagged unemployment rate were used as instruments in the specifications with higher-order terms for the contemporaneous unemployment rate.

Different specifications of the non-linear relationship between wages and unemployment have been tried. Two of these specifications are reported in the last two columns of Table 2 . Higher-order terms are found statistically insignificant and the standard errors for the coefficient of the linear term appear to be large. These results are in contrast with Blanchflower and Oswald (1994) and Gianella (2000) who found a convex relationship between wages and unemployment. 
The regressions were replicated using annual earnings data - a less theoretically desirable variable but nonetheless another measure of labor income- - to check for the robustness of the results to the definition of labor income. Estimates of the second-step regression using annual earnings are shown in Table 3. These results also allow a better comparison with results in Blanchflower and Oswald (as well as the results in Gianella), which were obtained by using annual earnings. The estimated coefficients for the unemployment rate are remarkably similar to the ones shown in Table 2.

Table 3. Parameter Estimates from the Annual Earnings Regression

\begin{tabular}{|l|c|c|}
\hline \multicolumn{2}{|c|}{ Second Step $^{1}$} \\
\hline Dependent Variable: & $\begin{array}{c}\text { Nominal Log Annual Earnings } \\
\text { Adjusted for Individual } \\
\text { Characteristics }\end{array}$ \\
\hline Independent Variable ${ }^{2}$ : & OLS & I.V. \\
Log Regional Unemployment Rate $\left(\mathrm{U}_{\mathrm{R}}\right)$ & $\begin{array}{c}-0.0356^{* *} \\
(0.0132)\end{array}$ & $\begin{array}{c}-0.0993^{* *} \\
(0.0296)\end{array}$ \\
\hline
\end{tabular}

Source: Enquête Emploi and authors’ calculations.

${ }^{1}$ Standard errors are in parentheses. ** and $*$ stand for $1 \%$ and $5 \%$ level of significance respectively.

${ }^{2}$ Other included independent variables are time dummies and regional dummies. Lagged unemployment rate was used as instrument for the contemporaneous rate in the I.V. estimation.

Estimates for the alternative specification including lagged wages are presented in

Table 4. The first set of I.V. results uses lagged unemployment as an instrument for the unemployment rate but not lagged wages. The coefficients are precisely estimated. The second set of estimates includes wages lagged twice as an instrument for wages lagged once to solve for the possibility that the fixed-effects estimates are biased due to the introduction of a lagged dependent 
variable and the small time dimension of the panel data. ${ }^{15}$ The point estimates are similar to the ones obtained with the first set of instruments but are not precisely measured. These results suggest that lagged wages might belong to the wage curve specification, but the low precision of the estimates leads to the acceptance of the static model as a better description of labor market functioning in France. In any case, if the estimated coefficients in the dynamic specification are taken at their face value, the implied long-run elasticity will be only just above -0.1 . The use of log annual earnings instead of log hourly wages in the dynamic specification does not change the results significantly. ${ }^{16}$

Table 4. Estimates of the Dynamic Specification

\begin{tabular}{|c|c|c|c|}
\hline \multicolumn{5}{|c|}{ Dependent variable: log hourly wage } \\
\hline Coefficients & OLS & I.V. 1 & I.V. 2 \\
\hline Lagged wage & $0.35^{* * *}$ & $0.33^{* * *}$ & 0.47 \\
& $(0.0685)$ & $(0.0632)$ & $-0.2958)$ \\
\hline Unemployment rate & $-0.02^{*}$ & $-0.08^{* * *}$ & $(0.0906)$ \\
& $(0.0108)$ & $(0.0271)$ & I.V.2 \\
\hline \multicolumn{4}{|c|}{ Dependent variable: log annual earnings } \\
\hline Coefficients & OLS & I.V.1 & 0.38 \\
\hline
\end{tabular}

${ }^{15}$ Nickell (1981) and Anderson and Hsiao (1982) have shown that the bias declines as the time dimension increases, approaching zero as $\mathrm{T}$ approaches infinity.

${ }^{16}$ Some papers use the existence of a possible dynamic specification for the wage curve as a test for the existence of a Phillips curve. While Blanchflower and Oswald (1994) and Gianella (2000) have not found any evidence for the importance of lagged wages in estimates of the wage curve, Blanchard and Katz (1997) and Bell (1996) suggest that this term may be important. The results shown here should be considered inconclusive. 


\begin{tabular}{|l|c|c|c|}
\hline & $(0.0706)$ & $(0.0676)$ & $(0.3297)$ \\
\hline Unemployment rate & -0.02 & $-0.07^{* *}$ & -0.09 \\
& $(0.0111)$ & $(0.0280)$ & $(0.1094)$ \\
\hline
\end{tabular}

Source: Enquête Emploi and authors’ calculations.

Notes:

1. The first set of I.V. estimates (I.V. 1) uses lagged unemployment as an instrument for contemporaneous unemployment. The second set of instruments (I.V. 2) includes twice-lagged wage as an instrument for lagged wages in the vector of instruments used in I.V. 1. Other independent variables included in the regression are time dummies and regional dummies.

2. Standard errors are in parentheses. $* * *, * *$, and $*$ stand for significance at $1 \%, 5 \%$, and $10 \%$ respectively.

\section{STRUCTURAL LABOR MARKET CHANGES IN FRANCE}

\section{(i) The immediate effect}

In all these specification, time dummies were included and they measure by how much the wage curve shifted in the period under study. They all point to a downward shift of equation (9).

Table 5 shows estimates for the time dummies from the preferred specification first presented in

Table 2. Another way of presenting these results is to treat shifts in the wage curve as movements in wages once labor force composition and unemployment effects are taken into account. The figures show that adjusted real wages grew 11 percent less than technological growth in the 1990s. In any case, these estimates can be mapped into shifts in the wage curve as shown in Figure 2.

As mentioned in Section II, many factors may have caused the measured shifts in the wage curve in France. Changes in unions’ preferences toward employment, a decline in their bargaining power, smaller fall back income if unemployed, lower tax wedge between labor income and unemployment income, technological changes and shifts in the elasticity of product market demand were variables highlighted by the model. Even if the inclusion of individual 
characteristics in the first stage regression controls for some aspects of potential unemployment income and tax wedges, there is no explicit way to identify the contribution of all these variables to the measured structural labor market changes. However, a quick look at some aggregate variables may give a hint of main factors behind the wage curve shifts.

Table 5. Parameter Estimates from the Hourly Wage Regression

\begin{tabular}{|c|c|}
\hline \multicolumn{2}{|c|}{ Second Step $^{1}$} \\
\hline Dependent Variable: & $\begin{array}{c}\text { Nominal Log Hourly Wage } \\
\text { Adjusted for Individual } \\
\text { Characteristics }\end{array}$ \\
\hline & I.V. \\
\hline $\begin{array}{c}\text { Independent Variable }{ }^{2}: \\
\text { Log (UR }\end{array}$ & $-0.0989^{* *}$ \\
Time dummies: & $(0.0295)$ \\
1992 & 0.0034 \\
& $(0.0046)$ \\
1993 & $0.0314^{* *}$ \\
1994 & $(0.0062)$ \\
1995 & -0.0003 \\
& $(0.0088)$ \\
1996 & $-0.0242^{* *}$ \\
1997 & $(0.0069)$ \\
1998 & $-0.0318^{* *}$ \\
& $(0.0078)$ \\
1999 & $-0.0435^{* *}$ \\
2000 & $(0.0085)$ \\
& $-0.0700^{* *}$ \\
Regional dummies & $(0.0071)$ \\
& $-0.0851^{* *}$ \\
& $(0.0073)$ \\
& $-0.1106^{* *}$ \\
& $(0.0039)$ \\
& YES \\
\hline
\end{tabular}

Source: Enquête Emploi and authors’ calculations.

${ }^{1}$ Standard errors are in parentheses. ${ }^{* *}$ stands for $1 \%$ level of significance.

${ }^{2}$ Lagged unemployment rate was used as instrument for the contemporaneous rate. 


\section{Figure 2. Shifts in the Wage Gurve}

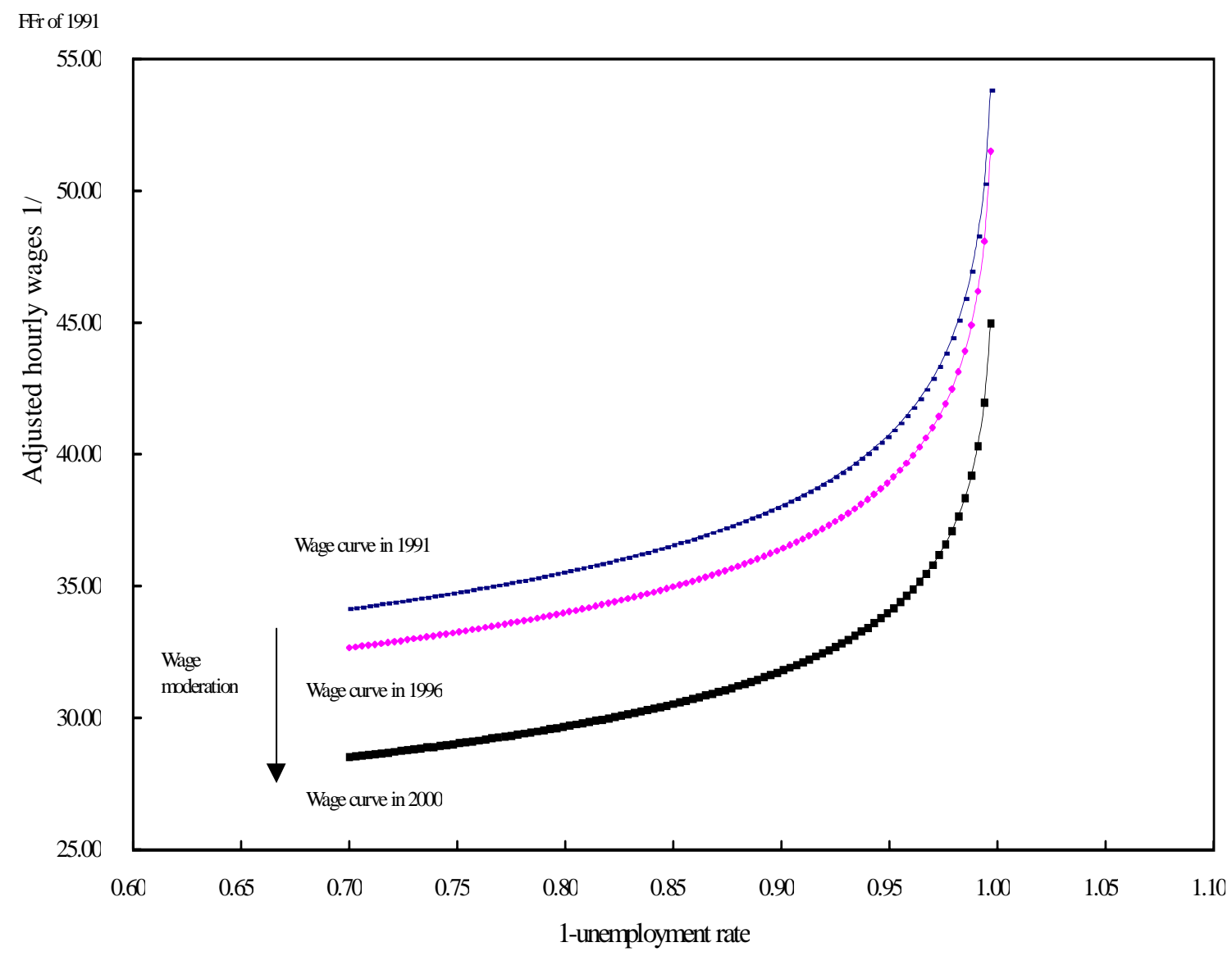

Source: authors' calculations.

1/ Adjusted for productivity, inflation and composition effectss.

First, we consider technological changes, which in equilibrium are equivalent to changes in the labor share (1- $\alpha$ in equation (9)). An increase in the labor intensity in production could cause wage demand to flag due to diminished marginal productivity of labor. But the share of labor income in GDP throughout the 1990s was broadly unchanged even if it had declined significantly in the 1980s. The flatness of the labor share in the value added of the business sector in France in most parts of the 1990s is evident in Figure 3 and does not seem capable of causing shifts in the wage-setting curve. 
Second, it is possible that inflation and productivity growth are imperfect proxies for the aggregate changes in the income received when unemployed, as proposed in the model derived above. For instance, they do not capture changes in labor market institutions such as unemployment insurance schemes or changes in marginal tax rates. It is well recognized that benefits as well as income taxes in France interact so as to provide disincentive to work. A number of recent studies show empirical evidence in support of this phenomenon (see Laroque and Salanié, 1999, 2000; Bourguignon and Bureau, 1999; Afsa and Guillemot, 1999). Given the narrow base of the income tax, high marginal rates at the low end of the income distribution result essentially from the withdrawal of benefits. According to Laroque and Salanié (1999), 57 percent of non-employment, termed as "voluntary unemployment", results from tax-benefit disincentives to work. However, OECD data for gross benefit replacement rates do not show significant changes in the ratio of benefits to labor income in the 1990s at least until 1997, the last available data point (see lower panel of Figure 3). Nevertheless, the rough nature of these indicators prevents a definitive answer to how important overall changes in unemployment income may be behind the shifts in the wage-setting relationship.

Third, the observed shift in the wage curve could have been caused by the process of globalization of production, which might have increased product market competition and the elasticity of product demand. Such a development would cause a downward shift in the wage curve because unions would take into account the adverse effects of high wage demands on production costs and, ultimately, on the amount produced and sold. It is hard to disentangle this effect from pure changes in unions' preferences and many analysts would in any case interpret 
this product market effect as a reduction of unions' bargaining power.

Figure 3. Labor Share and Replacement Rates in France

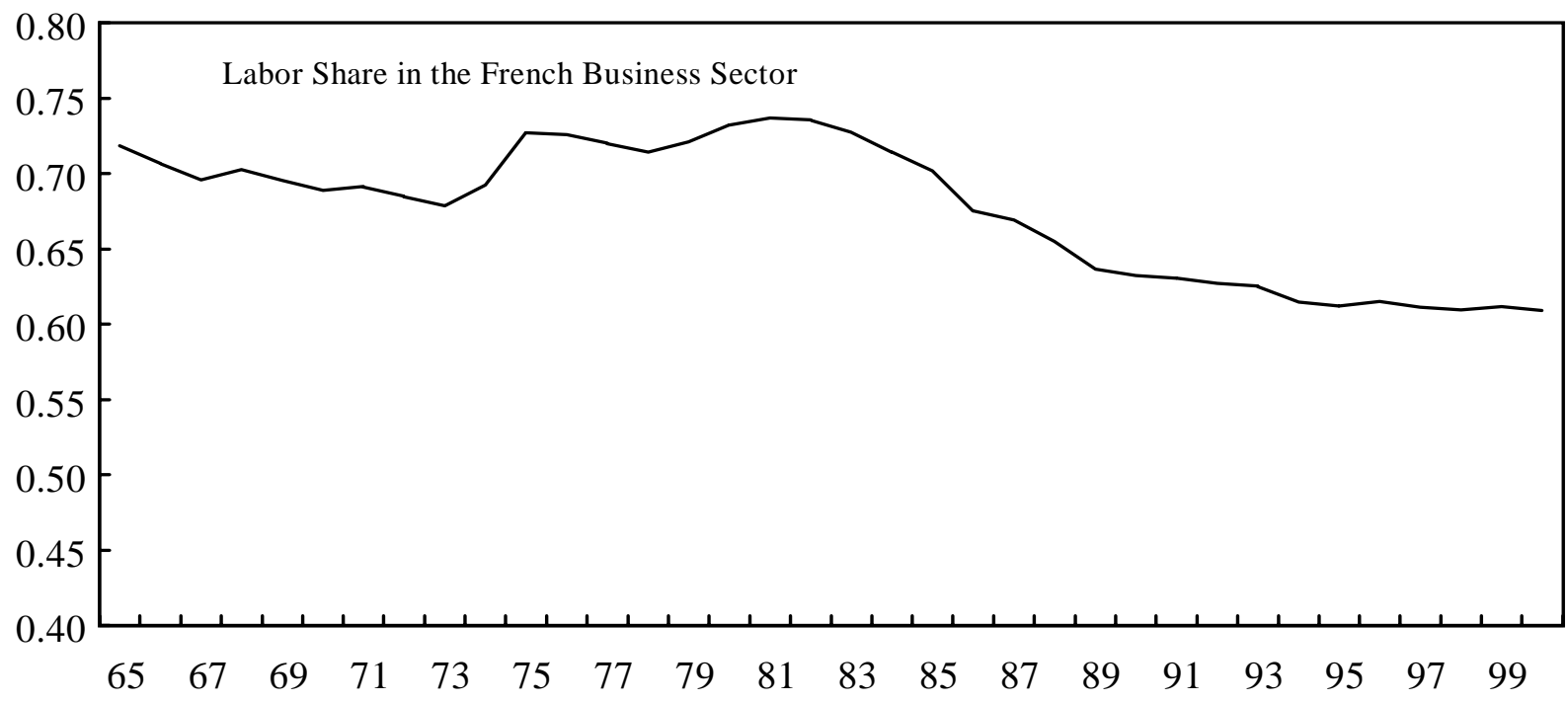

Source: OECD and authors' calculations.

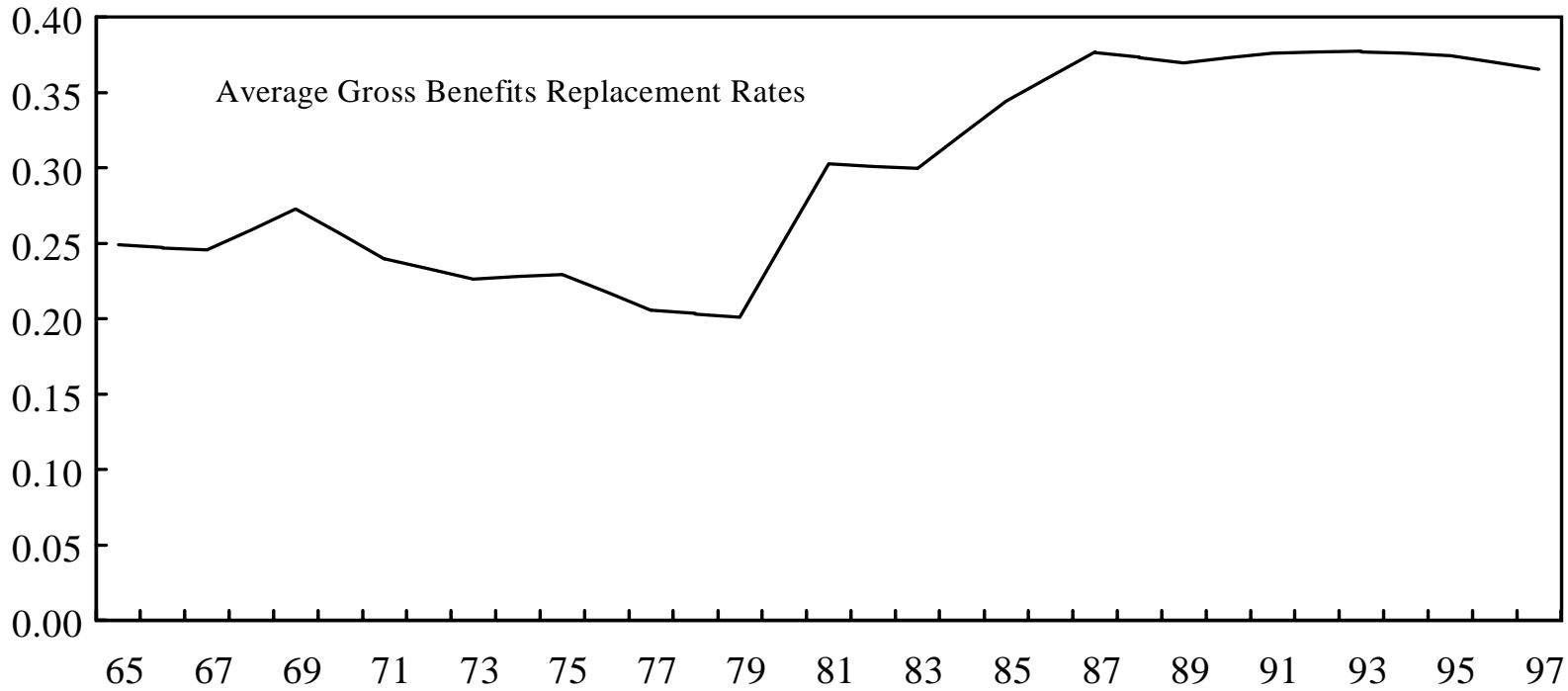

Source: OECD tax and benefits database and authors' calculations. 
Finally, shifts in union’s bargaining power or preferences toward employment, a wage moderation effect, could be behind the improved trade-off between unemployment and wages. Press articles describing the tamer wage negotiations associated to the introduction of the 35-hour workweek laws in France are consistent with this hypothesis. In addition, Estevão (2003) shows that larger expenditures in active labor market policies as a share of GDP were associated to significantly higher wage moderation across OECD countries. ${ }^{17}$ The substantial increase in expenditures in these programs, as well as their careful targeting, in France could have caused substantial wage moderation. In any case, there is no direct way to measure how important this effect would be.

\section{(ii) The long-run effect}

Figure 4 introduces a long-run labor demand in the model described in section II. In the long run-under the hypothesis of a small open economy —interest rates, the user cost of capital, and thus the marginal product of capital are determined in the world market and the labor demand is flat (LLD curve). Equations (2) and (9) are represented by the curves WS and SLD. As in Figure 2, real wages are defined as a ratio of the technology level.

Assuming, for the sake of argument, that the equilibrium unemployment rate in France in the 1990s was around 11 percent (this is the average unemployment rate for the decade), represented by point $\mathrm{E}$ in Figure 4, and that the wage setting curve, as estimated in (12), shifted down by about 71/2 percent (estimated movement from the mid-1990s to 2000) to point $\mathrm{E}_{1}$, firms

\footnotetext{
${ }^{17}$ Among the likely causes for this effect, active labor market policies keep displaced workers more attached to the labor market and, therefore, their presence exerts downward pressure on wage negotiations.
} 
will invest in new capital because low wages raise profit rates to a level above the user cost of capital. The short-run labor demand will then shift outwards, moving along the wage-setting curve, until the profit rate and the unit cost of capital are equal, point $E_{2}$. At this point, structural unemployment will be about half as high as in the 1990 s, i.e. about $5 \frac{1 / 2}{2}$ percent. ${ }^{18}$ Even though this reduction in equilibrium unemployment is quite large, this back-of-the-envelope calculation serves to show that the estimated shift in the wage-setting curve is far from trivial.

Figure 4. Shifts in the Wage-Setting Curve and Long-Run Adjustment

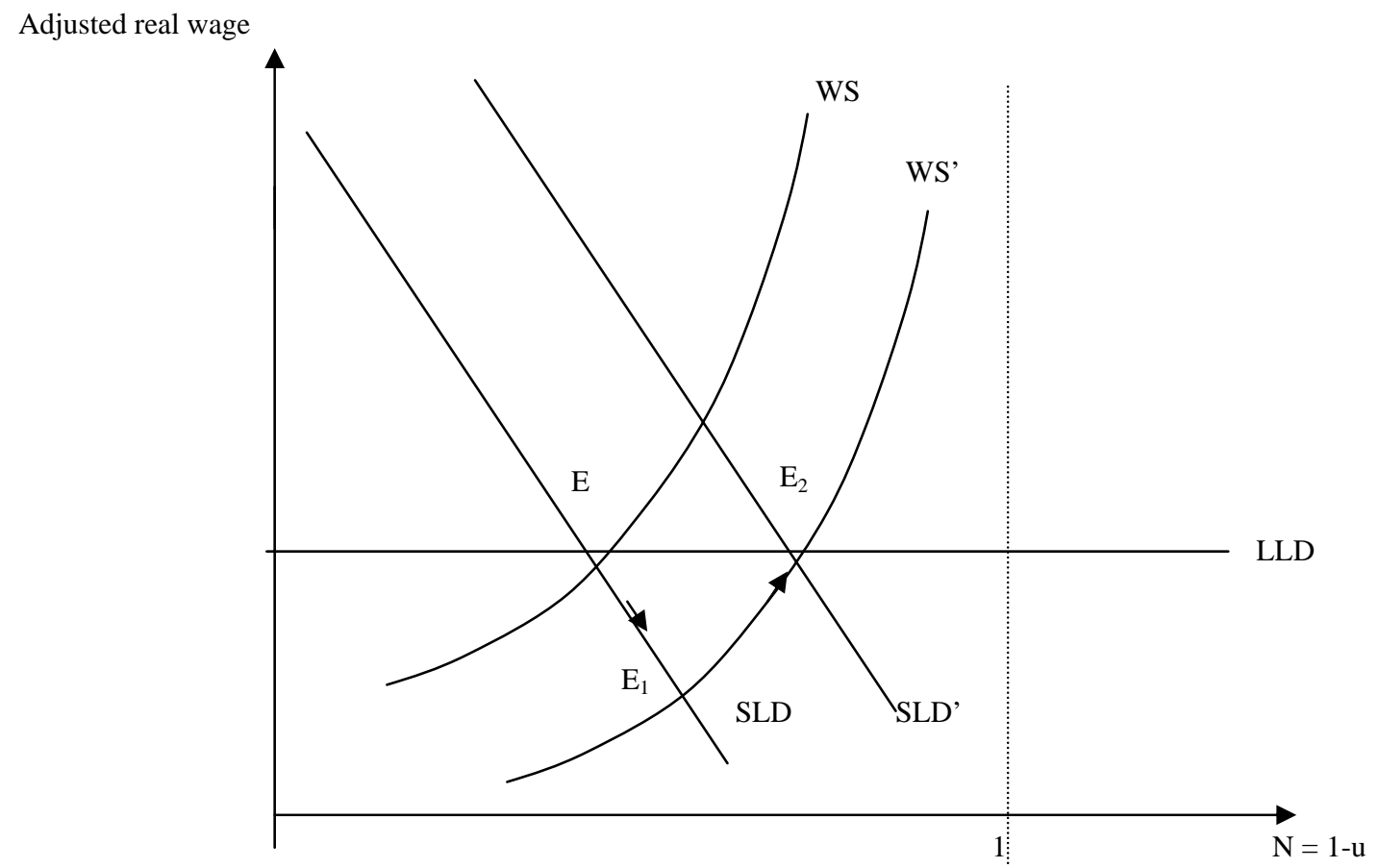

${ }^{18}$ This figure is obtained by solving the following system of equations for a given wage value: $\log (w)=-0.1 * \log (\mathrm{u} 90 \mathrm{~s})$ and $\log (\mathrm{w})=-0.075-0.1 * \log (\mathrm{uLR})$, where u90s and uLR are equilibrium unemployment rates in the 1990s and in the long run. 


\section{CONCLUSION}

In bargaining models, structural labor market changes can be captured by measured shifts in the equilibrium relationship between wages and unemployment (the wage-setting curve) while cyclical changes would be captured by movements along this equilibrium relationship. Micro econometric estimates using annual household level survey data, which allow the level of wages to be related to individual characteristics and local labor market conditions, indeed provide evidence of an important outward shift in the wage-setting curve in the 1990s in France. Such a shift, if maintained, is consistent with a halving of equilibrium unemployment rates in the longrun. In addition to this main result, the paper also provides new evidence for a -0.1 elasticity of wages with respect to the unemployment rate, therefore corroborating the wage curve thesis presented in Blanchflower and Oswald (1994), who had not included France in their sample of countries under study.

The causes for the improved trade-off between unemployment rates and wages are an area where further research is needed. This paper provided some discussion on possible factors, but, by its nature, the approach developed here is supposed to give only a summary statistic for the improvement in the structure of the French labor market. Continued research on the effect of

adopted policies in the 1990s, changes in workers' behavior toward wages and employment and other shifter variables is necessary. 


\section{APPENDIX I: Data Description}

The Enquête Emploi (EE) is an annual employment survey conducted by the Institut National de la Statistique et des Études Économiques (INSEE) in March of every year (with the exception of the year 1999 when the survey was undertaken in January). It collects information of individuals at the household level. The sample period used here runs from 1990 through 2000. Information for years prior to 1990 was not used due to the reporting of the wage variable in brackets as opposed to discrete numbers. From this dataset individual specific information is available on demographic characteristics (e.g., age, sex, marital status, number of children in the household), level of education, and labor market characteristics (e.g., labor force participation status, employment status, net monthly salary in the main job, number of hours worked in the main job during the week before the interview, industry and type of occupation) and the region of residence.

The dataset has a large sample of around 1.6 million observations for the population aged 15 years or above (about 146,000 observations, on average, for every year, see Table 6). Onethird of the sample from the previous year is replaced with new respondents every year. Nevertheless, individuals were treated as cross-sectional observations. Individuals between 15 and 64 years of age who reported positive net monthly salary in a regular job have been selected for the regression analysis. The selected sample excludes extreme observations, public sector employees, self-employed, apprentices, retired, inactive and those employed in the agricultural 
sector and military service. ${ }^{19}$ The final sample used in the estimation of equations (11) and (12) had 235,545 pooled cross-sectional observations for France over the period from 1990 through 2000. The paper departs from the convention of selecting prime-age male full-time workers with a view to controlling for the changing composition of the labor force by age, sex, employment status and other demographic and sectoral classification of occupation in the wage regression.

Table 6. Size of Full and Selected Sample

\begin{tabular}{|c|c|c|}
\hline Year & $\begin{array}{c}\text { Full Sample } \\
\text { (15 years and older) }\end{array}$ & Selected Sample \\
\hline 1990 & 136281 & 24209 \\
\hline 1991 & 137298 & 22833 \\
\hline 1992 & 141053 & 24001 \\
\hline 1993 & 146803 & 26005 \\
\hline 1994 & 151590 & 27111 \\
\hline 1995 & 151146 & 26845 \\
\hline 1996 & 150365 & 26799 \\
\hline 1997 & 148891 & 25901 \\
\hline 1998 & 149132 & 25700 \\
\hline 1999 & 148867 & 25055 \\
\hline 2000 & 148775 & 24892 \\
\hline
\end{tabular}

Source: Enquête Emploi.

The wage variable used here is the reported monthly salary net of social security contributions in the principal job (thus, it is the pre-income tax wage). Whenever the analysis refers to the annual salary, the monthly variable is multiplied by 12 . The annual labor earning variable is obtained by adding non-wage annual benefits to annual net salary. The hourly wage variable, on the other hand, has been calculated by dividing the net monthly salary by 4.33 and

${ }^{19}$ Extreme observations are characterized by a net salary that satisfies:

$\mid$ Individual Salary - Median salary $\mid>3 \times\left(75^{\text {th }}\right.$ Percentile $-25^{\text {th }}$ Percentile $)$. 
the number of hours worked in the main job in the week prior to the interview. Overtime hours are recorded in the weekly hours variable only when the individual worked more during the reference week than during a normal week. If the individual systematically works more than the legal working time (supplementary hours), these extra hours are not recorded separately. There is a potential measurement error in the weekly hours variable for those respondents who worked less than usual hours in the reference week due to illness, strike, weather condition, going to retirement or unemployment, or other plausible reasons for temporary drops in labor supply.

No information is available on individuals' tax liability when unemployed. The EE records the amount of the most recent unemployment insurance benefit payment. However, this variable has a large number of missing values, mostly because this information is not available for the persons who never received benefits in the past. It seems more appropriate to impute the income when unemployed to all individuals in the sample by using observable individual characteristics in the wage regression. To measure changes in the tax wedge, data on average income tax rates for different types of families from the OECD tax and benefits database were used. Thus, it is implicitly assumed that changes in average income tax rates did not affect aftertax unemployment income.

The regional unemployment rate, included in the list of explanatory variables in the second-step equation (12), shows wide disparity across regions over time ranging from a low of 4.84 percent in 1990 to 19.6 percent in 1996 (Table 7). This wide regional variation improves the identification of a relationship between wages and the unemployment rate that would have otherwise been obtained by using only aggregate time series data. 


\section{APPENDIX II}

Table 7. Weighted Regional and National Unemployment Rate (In percent)

\begin{tabular}{crrrrrrrrrrr}
\hline Region & 1990 & 1991 & 1992 & 1993 & 1994 & 1995 & 1996 & 1997 & 1998 & 1999 & 2000 \\
\hline & & & & & & & & & & & \\
1 & 7.08 & 6.84 & 7.91 & 9.75 & 11.16 & 10.24 & 10.92 & 11.02 & 10.69 & 10.37 & 8.57 \\
2 & 11.42 & 9.78 & 11.33 & 12.87 & 12.74 & 12.41 & 12.43 & 12.81 & 12.98 & 13.03 & 11.06 \\
3 & 11.70 & 9.57 & 10.65 & 12.13 & 13.25 & 12.60 & 10.84 & 14.13 & 12.58 & 13.21 & 11.46 \\
4 & 9.71 & 10.44 & 10.82 & 11.30 & 13.08 & 12.85 & 12.70 & 12.71 & 14.08 & 13.92 & 10.78 \\
5 & 8.89 & 8.08 & 8.74 & 9.73 & 11.14 & 9.60 & 10.85 & 11.46 & 10.32 & 10.64 & 8.08 \\
6 & 10.55 & 8.98 & 8.49 & 8.97 & 11.00 & 10.19 & 10.78 & 11.70 & 10.48 & 9.62 & 8.26 \\
7 & 7.86 & 9.36 & 11.10 & 10.00 & 11.55 & 10.45 & 10.62 & 11.72 & 9.59 & 10.25 & 9.25 \\
8 & 13.56 & 14.18 & 15.40 & 16.10 & 17.43 & 17.70 & 18.57 & 18.73 & 18.55 & 17.83 & 16.66 \\
9 & 7.98 & 8.44 & 10.32 & 11.24 & 12.19 & 11.46 & 11.58 & 11.76 & 10.95 & 11.05 & 9.68 \\
10 & 4.84 & 4.86 & 5.69 & 8.00 & 8.82 & 7.24 & 7.57 & 7.98 & 7.84 & 7.45 & 6.35 \\
11 & 7.62 & 7.32 & 9.27 & 9.55 & 9.58 & 9.18 & 9.31 & 9.34 & 9.96 & 9.30 & 7.86 \\
12 & 8.84 & 8.83 & 10.85 & 9.87 & 11.77 & 10.03 & 11.93 & 11.30 & 11.91 & 11.68 & 9.08 \\
13 & 8.46 & 9.15 & 8.86 & 9.90 & 9.51 & 9.63 & 9.67 & 10.09 & 9.17 & 9.02 & 7.21 \\
14 & 10.95 & 11.63 & 10.75 & 12.04 & 11.47 & 11.33 & 9.75 & 10.85 & 10.52 & 10.81 & 8.11 \\
15 & 10.54 & 10.83 & 11.04 & 10.92 & 13.25 & 11.83 & 12.54 & 12.06 & 10.53 & 11.81 & 11.01 \\
16 & 8.15 & 8.61 & 10.02 & 10.66 & 12.47 & 11.94 & 11.99 & 12.18 & 10.12 & 11.03 & 9.89 \\
17 & 10.68 & 9.42 & 8.67 & 8.03 & 10.01 & 8.68 & 9.62 & 9.55 & 8.45 & 9.32 & 7.77 \\
18 & 7.10 & 6.93 & 8.12 & 10.57 & 11.78 & 10.50 & 10.15 & 10.35 & 9.73 & 9.70 & 7.99 \\
19 & 8.41 & 8.68 & 10.61 & 10.07 & 11.19 & 10.46 & 10.84 & 10.30 & 9.69 & 10.08 & 9.89 \\
20 & 14.38 & 13.66 & 15.12 & 15.90 & 18.57 & 16.05 & 19.60 & 18.56 & 18.57 & 17.20 & 16.37 \\
21 & 12.37 & 12.02 & 13.19 & 14.65 & 15.28 & 16.23 & 16.92 & 17.21 & 17.24 & 17.20 & 14.38 \\
National & 9.24 & 9.11 & 10.12 & 11.21 & 12.47 & 11.67 & 12.18 & 12.38 & 11.90 & 11.82 & 10.09 \\
Min & 4.84 & 4.86 & 5.69 & 8.00 & 8.82 & 7.24 & 7.57 & 7.98 & 7.84 & 7.45 & 6.35 \\
Max & 14.38 & 14.18 & 15.40 & 16.10 & 18.57 & 17.70 & 19.60 & 18.73 & 18.57 & 17.83 & 16.66 \\
Std & 2.34 & 2.22 & 2.28 & 2.25 & 2.42 & 2.58 & 3.01 & 2.85 & 3.08 & 2.84 & 2.81 \\
\hline & & & & & & & & & & &
\end{tabular}

Source: Enquête Emploi and authors’ calculations. 


\section{DETAILED REGRESSION RESULTS}

Table 8. Results of the First-Step Regression

\begin{tabular}{|c|c|c|c|c|}
\hline \multirow[b]{3}{*}{ Independent variables } & \multicolumn{4}{|c|}{ Dependent variable } \\
\hline & \multicolumn{2}{|c|}{ Nominal log hourly wage } & \multicolumn{2}{|c|}{ Nominal log annual earnings } \\
\hline & Parameter & Standard & Parameter & Standard \\
\hline & estimate & error & estimate & error \\
\hline Constant & 2.7694 & 0.0176 & 9.9114 & 0.0160 \\
\hline Female & -0.1147 & 0.0016 & -0.1510 & 0.0014 \\
\hline Age & 0.0555 & 0.0007 & 0.0593 & 0.0007 \\
\hline Age*Age & -0.0006 & 0.0000 & -0.0006 & 0.0000 \\
\hline Number of children & -0.0110 & 0.0005 & -0.0141 & 0.0005 \\
\hline Married & 0.0339 & 0.0014 & 0.0373 & 0.0013 \\
\hline Full-time status & 0.0177 & 0.0023 & 0.4770 & 0.0020 \\
\hline \multicolumn{5}{|l|}{ Education: } \\
\hline $\mathrm{JH}$ & 0.1824 & 0.0105 & 0.1641 & 0.0096 \\
\hline TD & 0.1035 & 0.0057 & 0.1029 & 0.0051 \\
\hline BAC & 0.2016 & 0.0094 & 0.2152 & 0.0085 \\
\hline $\mathrm{BAC}+2$ & 0.2748 & 0.0159 & 0.2685 & 0.0143 \\
\hline $\mathrm{BAC}+4$ & 0.4276 & 0.0124 & 0.4499 & 0.0113 \\
\hline \multicolumn{5}{|c|}{ Interaction of age groups and education: } \\
\hline g1*no-diploma & -0.0979 & 0.0058 & -0.0979 & 0.0052 \\
\hline g1*JH & -0.2885 & 0.0122 & -0.2784 & 0.0110 \\
\hline g1*TD & -0.0302 & 0.0063 & -0.0155 & 0.0057 \\
\hline g1*BAC & -0.1462 & 0.0103 & -0.1774 & 0.0094 \\
\hline g1*BAC+2 & -0.2188 & 0.0171 & -0.2268 & 0.0155 \\
\hline g1*BAC+4 & -0.3893 & 0.0194 & -0.4703 & 0.0178 \\
\hline g2*no-diploma & -0.0397 & 0.0044 & -0.0389 & 0.0040 \\
\hline g2*JH & -0.1518 & 0.0106 & -0.1237 & 0.0097 \\
\hline g2*TD & -0.0772 & 0.0056 & -0.0682 & 0.0050 \\
\hline g2*BAC & -0.1284 & 0.0094 & -0.1311 & 0.0086 \\
\hline g2*BAC+2 & -0.1711 & 0.0159 & -0.1425 & 0.0144 \\
\hline g2*BAC+4 & -0.2571 & 0.0124 & -0.2462 & 0.0114 \\
\hline \multicolumn{5}{|l|}{ Economic sectors: } \\
\hline Utilities & 0.0986 & 0.0039 & 0.0637 & 0.0035 \\
\hline Construction & -0.0235 & 0.0021 & -0.0237 & 0.0019 \\
\hline Retail trade & -0.0723 & 0.0018 & -0.0623 & 0.0016 \\
\hline Transport & 0.0221 & 0.0024 & 0.0201 & 0.0022 \\
\hline Financial sector & 0.0675 & 0.0029 & 0.0641 & 0.0026 \\
\hline Real estate & -0.0919 & 0.0046 & -0.0884 & 0.0042 \\
\hline
\end{tabular}




\begin{tabular}{|c|c|c|c|c|}
\hline \multicolumn{5}{|c|}{ Table 8. (continued) } \\
\hline \multicolumn{5}{|l|}{ Occupation categories: } \\
\hline Craftsmen and owner of related small business & -0.2060 & 0.0178 & -0.0772 & 0.0163 \\
\hline Small business owner in trade and services & -0.1032 & 0.0181 & 0.0225 & 0.0166 \\
\hline Head of firms with 10 or more employees & 0.3158 & 0.0188 & 0.5084 & 0.0172 \\
\hline Professionals & 0.1913 & 0.0485 & 0.1471 & 0.0436 \\
\hline Managers in the public sector & 0.2060 & 0.0159 & 0.1835 & 0.0143 \\
\hline Professors and scientists & 0.2959 & 0.0147 & 0.2171 & 0.0132 \\
\hline Managers in the private sector & 0.2625 & 0.0101 & 0.3444 & 0.0092 \\
\hline Engineers and technical experts & 0.2958 & 0.0101 & 0.3555 & 0.0092 \\
\hline Teachers and related occupations & 0.0869 & 0.0178 & 0.0311 & 0.0162 \\
\hline Workers in health and social services & -0.0491 & 0.0116 & -0.0883 & 0.0106 \\
\hline Clergymen & -1.1292 & 0.2792 & -1.0833 & 0.2665 \\
\hline Middle-management in the public admin. & -0.0019 & 0.0098 & 0.0026 & 0.0090 \\
\hline Middle-management in the private sector & 0.0451 & 0.0126 & -0.0143 & 0.0115 \\
\hline Technicians & 0.0136 & 0.0099 & -0.0359 & 0.0090 \\
\hline Foremen & 0.0428 & 0.0100 & 0.0171 & 0.0091 \\
\hline Civil servants & -0.1703 & 0.0109 & -0.2356 & 0.0099 \\
\hline Police and armed forces officers & -0.1657 & 0.0140 & -0.2140 & 0.0128 \\
\hline Clerical workers in the private sector & -0.1058 & 0.0098 & -0.1480 & 0.0090 \\
\hline Sales workers & -0.2398 & 0.0099 & -0.2790 & 0.0091 \\
\hline Service workers to individuals or households & -0.4656 & 0.0119 & -0.4769 & 0.0109 \\
\hline Skilled blue-collars in industry & -0.1414 & 0.0098 & -0.2089 & 0.0089 \\
\hline Skilled manual workers & -0.1937 & 0.0099 & -0.2517 & 0.0090 \\
\hline Drivers & -0.2568 & 0.0101 & -0.2548 & 0.0092 \\
\hline Maintenance, transportation and storage workers & -0.1629 & 0.0101 & -0.2301 & 0.0093 \\
\hline Low-skill blue-collars in industry & -0.2557 & 0.0098 & -0.3192 & 0.0090 \\
\hline Low-skill manual workers & -0.3671 & 0.0101 & -0.4773 & 0.0093 \\
\hline Number of observations & 235,562 & & 259,831 & \\
\hline Adjusted $\mathrm{R}^{2}$ & 0.51 & & 0.66 & \\
\hline F-Statistic & 875.2 & & 1733.1 & \\
\hline
\end{tabular}

Source: Enquête Emploi and authors' estimation.

Notes:

Bold coefficients are significant at 1 percent level;

Age group dummies: if $15<=$ age $<25$ then $\mathrm{g} 1=1$, else g1 $=0$; if $25<=$ age $<55$ then g2 = 1, else g2 = 0; if 55 $<=$ age then $\mathrm{g} 3=1$; else g3 $=0$.

Educational categories: $\mathrm{JH}=$ Junior-High school diploma; $\mathrm{TD}=$ Technical diploma; $\mathrm{BAC}=$ Baccalaureat; $\mathrm{BAC}+2=$ $\mathrm{BAC}+2$ years of education; $\mathrm{BAC}+4=\mathrm{BAC}+$ minimum of 4 years of education.

Control group: Male, single, part-time, no-school diploma, interaction between g3 age group and education variables, industrial sector, and journalists, entertainers and artists. 


\section{REFERENCES}

Abowd, John M. and F. Kramarz, 1993, “A Test of Negotiation and Incentive Compensation Models Using Longitudinal French Enterprise Data,” in J.C. van Ours, G.A. Pfann and G. Ridder, eds., Labour Demand and Equilibrium Wage Formation, North Holland, Amsterdam, pp.111-146.

Abowd, John and T. Lemieux, 1993, “The Effects of Product Market Competition on Collective Bargaining Agreements: The Case of Foreign Competition in Canada,” Quarterly Journal of Economics, pp.983-1014.

Afsa, Cédric and Guillemot, Danièle, 1999, "Plus de la moitié des sorties du RMI se font grâce à l'emploi,” INSEE Première, No. 632, February.

Anderson, T. W. and Cheng Hsiao, 1982, "Estimation of Dynamic Models with Error Components,” Journal of the American Statistical Association, pp. 589-606.

Bell, B., 1996, “Wage Curve or Phillips Curve?” Mimeo, Nuffield College, Oxford.

Blanchard, Olivier, 1997, “The Medium Run,” Brookings Papers on Economic Activity, 2, pp. 89-158.

_ 2000, “The Economics of Unemployment: Shocks, Institutions, and Interactions,” Lionel Robbins Lecture, London School of Economics, October. 
, and Larry Katz, 1997, "What We Know and Do Not Know About the Natural Rate of Unemployment,” Journal of Economic Perspectives, Vol.11, No.1, pp.51-72.

Blanchflower, David G. and Oswald, Andrew J., 1994, The Wage Curve, MIT Press.

and Oswald, Andrew J., 1995, “An Introduction to the Wage Curve,” Journal of Economic Perspectives, Vol.9, No.3, pp.153-167.

Bourguinon, François and Bureau, Dominique, 1999, L’architecture des prélèvements en France, Conseil d’Analyse Economique, Paris.

Card, David, 1995, “The Wage Curve: A Review,” Journal of Economic Literature, Vol. XXXIII, June, pp.785-799.

Crépon, Bruno and Rozenn Dezplatz, 2001, “Une Nouvelle Évaluation des Effets des Allégements de Charges Sociales sur les Bas Salaires,” Economie et Statistique, No. 348, pp. 3-24, August.

Daveri, Francesco and Tabellini, Guido, 2000, “Unemployment, Growth and Taxation in Industrial Countries,” Economic Policy, April, pp.49-104.

Decressin, Jorg, Marcello Estevão, Phillip Gerson and Christopher Klingen, 2001, “Job-Rich 
Growth in Europe,” Background paper to the German 2001 Article IV consultation, IMF.

Estevão, Marcello, “Do Active Labor Market Policies Increase Employment?” , IMF Working Paper, WP/03/234, 2003.

Gianella, Christian, 2000, “Local Unemployment and Wages,” Working Paper, INSEE, November.

Hagneré, Cyrille and Alain Trannoy, 2001, “L’impact conjugué de trois ans de réforme sur les trappes à inactivité,” Économie et Statistique, INSEE, 346/347:161-185.

Laroque, Guy and Salanié, Bernard, 2000, “Une décomposition du non-emploi en France,” Economie et Statistique, INSEE, 331(1):47-66.

—_, 1999, "Prélèvement et transferts sociaux: une analyse descriptive des incitations financières au travail,” Économie et Statistique, 328(8), pp.3-20.

Layard, R., S. Nickell and R. Jackman, 1991, Unemployment, Oxford, Oxford University Press.

Nickell, S., 1981, “Biases in Dynamic Models with Fixed Effects,” Econometrica, 49, pp.1417-1426. 
Nickell, S. and R. Layard, 1997, “Labour Market Institutions and Economic Performance,” Working Paper, Oxford : Institute of Economics and Statistics, Oxford University.

Moulton, Brent R., 1986, “Random Group Effects and the Precision of Regression Estimates,” Journal of Econometrics, August, 32(3), pp.385-97.

— 1990, “An Illustration of a Pitfall in Estimating the Effects of Aggregate Variables on Micro Units,” Review of Economics and Statistics, May, 7292, pp.334-38.

OECD, 1999a, Benefits Systems and Work Incentives, OECD, Paris.

— 1999b, Employment Outlook, OECD, Paris.

—, 2001, Employment Outlook, OECD, Paris.

Pisani-Ferry, J., 2000, Plein Emploi, Conseil d’Analyse Economique, Paris. 